\title{
Methodological Aspects of the Use of Software in the Teaching of Engineering Disciplines: Tasks, Problems and Prospects
}

\author{
Irina K. Romanova ${ }^{1 *}$ \\ ${ }^{1}$ Bauman Moscow State Technical University, 2nd Baumanskaya str., 5/1, 105005, Moscow, Russia
}

\begin{abstract}
The main directions of improving training that can be achieved as part of the introduction of new software in the teaching of engineering disciplines are considered. The necessity of ensuring the continuity of training within the framework of a unified concept of using software tools is noted. The analysis of needs in the formation of new competencies based on the results of a survey of graduate students of BMSTU, and the views of employers, which showed the closeness of the representations of students, teachers and employers. It is noted that the developed software application technologies should guarantee their inextricable link. New approaches to the teaching of engineering disciplines based on computer modeling, which are used in world practice, are considered. Trends in the application of modeling technologies, including the use of integrated software products, are noted. The main modern trends are active training and teamwork, group training. These computer technologies have taken the project approach to learning to a new stage. New software products allow not only the formation of special competencies, but also provide the opportunity to acquire important communication skills. New opportunities for student motivation are opening up. Access to an open electronic educational environment, including open packages of applied engineering design programs allows you to create self-education skills, without which it is impossible for an engineer to work in rapidly changing conditions. The active role of the teacher in effective and competent self-education is noted.
\end{abstract}

\section{Introduction}

\subsection{Backgrounds}

The deep internal connection of the needs and capabilities of both society as a whole and the hotel individual, which is the engine of progress, at each stage of development has its own forms, features, and trends. Currently, one of the most important areas is the rapid development of information technologies, which have changed a lot in economic, social, industrial, educational aspects.

* Corresponding author: irina.romanova@bmstu.ru 
The common name digitalization requires analysis and understanding of manifestations in specific areas. One of these areas, looking to the future and largely determining the development of society, is the digitalization of education.

Let us analyze what needs and opportunities are currently available in the field of higher education, using the example of the use of new computer technologies in the training of engineering personnel.

To make such an analysis fruitful, we will identify methodological aspects of the use of digital technologies, focusing on the use of relevant and advanced software. At the same time, the main criteria for effectiveness will be the ability to provide answers to new challenges and needs, the advancing development of technologies, and the mutual enrichment of different areas of society.

Some aspects of the use of computer technology were considered in the works of the author $[1,2]$. This article discusses a wide range of tasks of using computer technology in the training of specialists, taking into account both international experience and training concepts at BMSTU and the author's experience of methodological work and teaching disciplines of the direction "Mechatronics and Robotics".

\subsection{New approaches in the world practice of teaching engineering disciplines based on computer modeling. Review}

Design approach. Currently, the abbreviation Project-Based Learning (PBL) has been fixed [3]. The use of PBL is widely recognized among students and employers. However, some problems persist, such as:

- improving interaction with the course of design basics - design calculations;

- enhanced expert judgment;

- expansion of the project coordination group,

- updating tools for collecting and analyzing data.

Engineering design. Existing studies show that D / A / A (Disassemble, Analyse, Assemble-Disassembly, Analysis, Assemblage) actions can become popular methods for providing students with engineering design and enriching their practical experience [4].

Project management. Scrum is a flexible Agile Methodology project management framework with extensive application capabilities for managing and monitoring iterative and incremental projects of all types.

Active training and teamwork, group training. In [5] it was shown that analogy (realistic examples) is the best teaching technique for the active learning process. Students rated lecture videos and brainstorming. This study suggests that there is a need for a paradigm shift from traditional learning to active learning.

Paper [6] analyzed the advantages and disadvantages of using project-based learning (PBL) in combination with collaborative learning (CL) and industry best practices integrated with information and communication technologies, open source software and open source hardware, for the task of designing specialized microcontrollers and developing embedded systems. The new system is called cooperative PBL (CPBL).

Based on the Scrum project management methodology [7] - project management in the field of computer software product development, eduScrum was developed, the essence of which is the delegation of greater responsibility for the management of the educational process from teachers to students, both in terms of time and action management. This flexibility allows for several profiles of students to actively participate in the learning process, implementing the ideas of mutual learning and correction of interactions [8].

Paper [9] described how the software industry requested professionals with teamwork, data analysis, and problem solving skills, which further complicates the task of educators in 
software engineering (SE). The adoption of active learning methodologies, such as group learning (TBL), was one of the learning strategies.

STEM education. EdSTEM [10] is a term used to generically refer to the teaching of disciplines within its field - science, technology, engineering and mathematics, as well as an interdisciplinary approach to teaching, which increases students' interest in areas related to STEM and improves problem-solving and critical skills analysis.

New approaches in the use of information technology. In [11] a set of new methodologies used in teaching computer science is shown. The theory of genetic-cognitive psychology and the psychology of dialectics served as the basis for the development of the following methodologies: game theory, constructive approach, personalized training, problem solving, joint training. The results show [12] that multimedia teaching aids can be very useful for creating a solid foundation for further research. They act as multipliers for students' capacity building efforts and promote self-learning.

An integrated approach to the use of computer technology has found wide application in the construction industry [13] BIM (Building Information Modeling) BIM Methodology (Building Information Modeling).

Operations Research (OR). It covers areas such as [14] management, business, economics, electrical engineering, civil engineering, chemical engineering, and related fields.

New software development concepts. DevOps, a new concept for software development, is described in [11].

A virtual reality. Virtual reality is widely used in a variety of design tasks. Virtual reality technologies find their application by modeling interdisciplinary industrial projects. The skills acquired in the process of mastering virtual reality methods are as follows: a methodological approach to practical engineering tasks, teamwork, work in interdisciplinary groups, and time management [15]. Virtual reality technologies are used in simulations, for example, in training naval officers [16]. Important here is the development of real-life scenarios in combination with e-learning. The use of augmented reality technologies [17] will increase interest in the study of disciplines, improve the process and learning outcomes [18]. Virtual laboratories are complemented by remote laboratories [19].

In [20], engineering tasks are described that work on platforms with consistent and intelligent three-dimensional virtual models. Methodology for Building Information Modeling (BIM).

Information technology in the control of learning. These technologies must fit in, i.e., is an integral part of the main software product.

Examples of such an implementation: content management e-learning [19], CODY courses MATLAB.

Digital teaching methods are increasingly found in university education, and digital icons [21] offer a new and evolving way of motivating and encouraging students to achieve learning. Each digital icon has been aligned with learning assessment results. In particular, two skipping methods were tested during the biennium: an external open badge that indicates completion of the acquisition of certain skills that students could show through their LinkedIn accounts in support of their resumes; and an internal digital icon corresponding to predefined university performance levels using the Blackboard University Learning Management System (LMS).

Theory of motivation and computer modeling. In [22], five criteria five-factor theory of adult learner motivation are taken from the theory of motivation of an adult student Raymond Vlodkovsky (the experience of teachers, relevance of content, choice of application, practice (action plus reflection) and group work). They were proposed as the basis for the development of engineering development curricula. 
New concepts for preparing and developing curricula. A wide range of established methodologies in the educational field is described in [23]. Seven methodologies are outlined:

- Case Study;

- Grounded Theory;

- Ethnography;

- Action Research;

- Phenomenography;

- Discourse Analysis;

- Narrative Analysis.

In [24, 25], a methodology is proposed for developing curricula for professional software engineers based on the target model. The strategic goal of professional software engineers is determined, and three tactical educational sub-goals for the acquisition of advanced software development technologies, software development practices and the formation of a leadership philosophy are deduced.

In [26] it was shown that software engineering is a key topic in computer education. In order for this course to remain relevant and relevant, it is important that students are familiar with current software development tools and techniques. Features such as project management, requirements tracking, configuration management, collaboration tools and team communication are ideal for practical work. In the project's boundaries. software engineering methodology (SEM)

In [27], case study research methodology (CSM) technology was described.

In [28] a pedagogical strategy is described, which the authors call UnLecture. It lies in bridging the gap between software, engineering, and computer education.

Open Learning and Online Courses. Massive Open Online Courses (MOOCs) are described in [29]. Massive Open Online Courses (MOOC) have recently gained high popularity among various universities and even in global societies. An important factor in their success in the effectiveness of teaching and learning is the assignment of grades. Traditional methods for assessing assignments do not scale and do not provide timely or interactive feedback to students. To solve these problems, [29] introduced interactive training based on games and the Pex4Fun learning platform - browser-based learning

An important issue is the availability of information. The HAL system is described in [30] - it is an interdisciplinary open access archive for storing and disseminating scientific research documents, whether they are published or not

Internet of things. The Internet of things can be understood as the infrastructure of a dynamic global network with the bandwidth of self-configuration, based on standard communication protocols, where things - physical and virtual - have identity, physical attributes and virtual personalities. In [49]. A methodology based on model-driven engineering with various levels of abstraction, points of view and granularity is proposed.

Use of mobile devices. A new learning and software development framework that combines Agile methodologies with the Challenge-Learning (CBL) framework [31]. Combining Challenge-Based Learning with the Scrum Framework. Mobile application development Mobile learning (m-learning). The development of software for mobile devices to support learning is essential for the effective implementation of mobile and mobile learning environments (MLE). 


\section{Development of methodological aspects of the use of computer technology in the teaching of engineering disciplines: Three points of view on modern training using digital technologies}

\subsection{Needs for the formation of new competencies: students' view}

Questioning of undergraduates of the faculty of SM MSTU. N.E. Bauman showed that students want to be well prepared for their professional life and expect more courses with the practical application of theoretical knowledge gained in the learning process. Basic needs and expectations relate to the following aspects:

- linking items to practical tasks; more applied practice. An increase in the volume of hours of laboratory work with the possibility of working in classrooms using personal computers; an increase in the number of workshops, excursions, practices and lectures of representatives of enterprises to grow;

- the use of relevant and new materials in teaching, more visibility and relevant information;

- enhancing interaction with enterprises and departments in related fields;

- inclusion in the program of hardware and software semi-natural modeling for studying the physics of the behavior of designed objects;

- a deeper study of modern programming languages: C \#, JavaScript, Phyton, R and others;

- time management, planning your studies with the help of new software products;

- group course projects of students with a separate plan for each student and appropriate control;

- development of a project from setting a task to a prototype.

2.2 The view of teachers: the main directions of improving training that could be achieved as part of the introduction of new software in the framework of engineering training

They are:

- strengthening of practical orientation;

- group design;

- new means of virtual reality;

- strengthening of intersubject communications;

- end-to-end design using modern means of information technology;

- New software engineering technologies.

\subsection{Employers needs}

According to the Institute of Mechanics Problems of the Russian Academy of Sciences, which analyzed the basic requirements for training specialists in the field of robotics and mechatronics, graduates should be ready, among other things, to use computer technology, including software tools:

- comparative analysis of options for possible fundamental decisions on algorithmic and software products;

- development of structural and functional diagrams of robots and circuit diagrams of devices using computer-aided design; 
- selection of system-wide software tools and design of software systems that ensure the functioning of robots and robotic systems;

- applying a system-wide optimization strategy to build robots and robotic systems;

- development of project design and program documentation for the technical project for the product as a whole;

- development of mathematical models of robotic and mechatronic systems, their individual subsystems, analysis of mathematical models by computer simulation methods;

- modeling of objects and processes in order to analyze and optimize their parameters using available research tools, including standard and subject-oriented application packages;

- implementation of an experimental research program, including the selection of technical equipment and processing of results.

\subsection{Discussion}

The analysis of the needs in the formation of new competencies showed the similarity of representations among students, teachers and employers. In the process of preparation, there is an interaction of three participants: student - teacher - employer. It is obvious that the developed technologies should provide this inextricable link.

\section{Implementation of the continuity of training on the example of teaching robotics and mechatronics in a two-level bachelor- master system}

\subsection{Bachelors}

Analysis of the plans of bachelors showed that at present almost all disciplines have a component that is somehow related to the use of software and computer technology in general. In Fig. 1. disciplines that directly use the software are highlighted. In recent years, the use of information technology has also been actively introduced into the teaching of mathematical and other general technical cycles. 


\begin{tabular}{|c|c|c|c|c|c|c|c|}
\hline Semester 1 & Semester 2 & Semester 3 & Semester 4 & Semester 5 & Semester 6 & Semester 7 & Semester 8 \\
\hline Foreign language & Foreign language & Foreign language & Foreign language & Foreign language & Foreign language & & \begin{tabular}{|l|} 
Russian \\
language and \\
speech culture
\end{tabular} \\
\hline Culturology & History & Jurisprudence & Political Science & & Philosophy & Economics & Economics \\
\hline $\begin{array}{l}\text { Mathematical } \\
\text { analysis }\end{array}$ & $\begin{array}{l}\text { Integrals and } \\
\text { differential equations }\end{array}$ & $\begin{array}{l}\text { Fundamentals of } \\
\text { probability theory } \\
\text { and mathematical } \\
\text { statistics }\end{array}$ & $\begin{array}{l}\text { theory of functions } \\
\text { of a complex } \\
\text { variable and } \\
\text { operational } \\
\text { calculus }\end{array}$ & $\begin{array}{l}\text { Theory of automatic } \\
\text { control }\end{array}$ & $\begin{array}{l}\text { Theory of automatic } \\
\text { control }\end{array}$ & \begin{tabular}{|l|} 
Theory of \\
automatic control
\end{tabular} & State exam \\
\hline Informatics & $\begin{array}{l}\text { Informatics } \\
\text { (Algorithmization and } \\
\text { Programming) }\end{array}$ & $\begin{array}{l}\text { Discrete } \\
\text { mathematics }\end{array}$ & & $\begin{array}{l}\text { Fundamentals of } \\
\text { digital technology }\end{array}$ & $\begin{array}{l}\text { Fundamentals of } \\
\text { computer aided design } \\
\text { MS and RTS }\end{array}$ & $\begin{array}{l}\text { Optimization } \\
\text { Methods in } \\
\text { Design } \\
\text { MS and RTS }\end{array}$ & $\begin{array}{l}\text { ModelingMS } \\
\text { and RTS }\end{array}$ \\
\hline $\begin{array}{l}\text { Engineering } \\
\text { graphics }\end{array}$ & Engineering graphics & $\begin{array}{l}\text { Engineering } \\
\text { graphics }\end{array}$ & $\begin{array}{l}\text { Metrology, } \\
\text { standardization } \\
\text { and certification }\end{array}$ & $\begin{array}{l}\text { Details of } \\
\text { mechatronics } \\
\text { modules, robots and } \\
\text { design fundamentals }\end{array}$ & $\begin{array}{l}\text { Details of mechatronic } \\
\text { modules, robots, and } \\
\text { design fundamentals. } \\
\text { Course project }\end{array}$ & $\begin{array}{l}\text { Fundamentals of } \\
\text { designingMS } \\
\text { and RTS }\end{array}$ & $\begin{array}{l}\text { DesigningMS } \\
\text { and RTS }\end{array}$ \\
\hline $\begin{array}{l}\text { ntroduction to } \\
\text { profile trainin }\end{array}$ & & Material resistance & $\begin{array}{l}\text { Fundamentals of } \\
\text { mechatronics and } \\
\text { robotics }\end{array}$ & $\begin{array}{l}\text { Design of MS and } \\
\text { RTS modules }\end{array}$ & $\begin{array}{l}\text { Electric drives of MS } \\
\text { and RTS }\end{array}$ & $\begin{array}{l}\text { Electric servo } \\
\text { drives } \\
\text { MS and RTS }\end{array}$ & $\begin{array}{l}\text { undergraduate } \\
\text { practice }\end{array}$ \\
\hline Chemistry & Physics & Physics & MaterialScience & $\begin{array}{l}\text { Automated } \\
\text { Technology } \\
\text { instrument } \\
\text { engineering and } \\
\text { mechanical } \\
\text { engineering }\end{array}$ & $\begin{array}{l}\text { Microprocessor } \\
\text { technology in } \\
\text { mechatronics and } \\
\text { Robotics }\end{array}$ & $\begin{array}{l}\text { Microprocessor } \\
\text { Devices } \\
\text { MS and RTS }\end{array}$ & $\begin{array}{l}\text { Fundamentals } \\
\text { of } \\
\text { management } \\
\text { of MS and } \\
\text { RTS }\end{array}$ \\
\hline
\end{tabular}

Fig. 1. Plan of bachelor.

\subsection{Master training}

The main components of the training of masters in mechatronics and robotics are presented in Fig. 2.

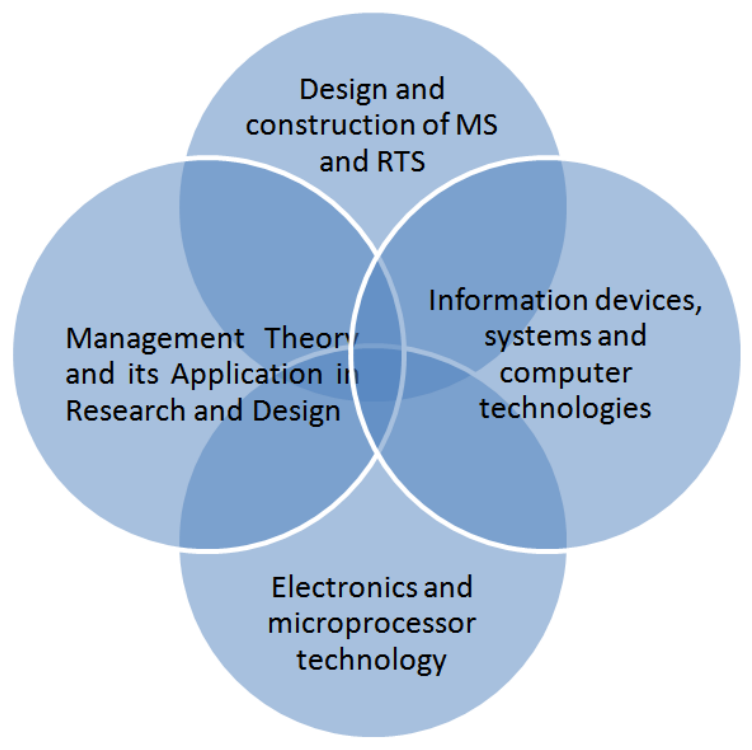

Fig. 2. Main components of the training of masters.

The table shows the data on the formation of master training programs in accordance with the requirements for competencies in the field of theoretical training and design of the main systems of robotics and mechatronics. 
Table 1. Requirements and master training programs.

\section{Groups of components used \\ in the structure of robotic and mechatronic systems}

Control systems.

\begin{tabular}{|c|c|}
\hline . & $\begin{array}{l}\text { Sections of in-depth study of the theory of automatic control. } \\
\text { Intelligent systems in mechatronics and robotics }\end{array}$ \\
\hline Algorithms and software & $\begin{array}{l}\text { Optimization methods and their application in the design of } \\
\text { control systems for objects of robotics and mechatronics. } \\
\text { Computer-aided design of robotic and mechatronic systems. } \\
\text { Modeling and research of robotic and mechatronic systems. } \\
\text { Methods, algorithms and software and hardware for autonomous } \\
\text { motion control of robotic and mechatronic systems }\end{array}$ \\
\hline Sensors & $\begin{array}{l}\text { Information systems and technologies in mechatronics and } \\
\text { robotics. } \\
\text { Modern electronic devices of robotic and mechatronic systems. } \\
\text { Methods, algorithms and software and hardware for autonomous } \\
\text { motion control of robotic and mechatronic systems }\end{array}$ \\
\hline Transport & Designing Mobile Robots \\
\hline Energy & $\begin{array}{c}\text { Motion design of robotic and mechatronic systems. } \\
\text { Designing Mobile Robots }\end{array}$ \\
\hline Design & Design of robotic and mechatronic systems \\
\hline Communication & $\begin{array}{l}\text { Microprocessor devices of motion control systems for robotic } \\
\text { and mechatronic systems. } \\
\text { Methods, algorithms and software and hardware of autonomous } \\
\text { motion control of robotic and mechatronic systems. } \\
\text { Information Management and Information Technology Project } \\
\quad \text { Management Technologies }\end{array}$ \\
\hline
\end{tabular}

Technological Payload

Masters program disciplines

Sections of in-depth study of control theory in mechatronics and

robotics.
Sections of in-depth study of the theory of automatic control. Intelligent systems in mechatronics and robotics

Optimization methods and their application in the design of control systems for objects of robotics and mechatronics.

Modeling and research of robotic and mechatronic systems.

Methods, algorithms and software and hardware for autonomous motion control of robotic and mechatronic systems

\section{robotics.}

Methods, algorithms and software and hardware for autonomous motion control of robotic and mechatronic systems

Manipulator design.

The use of mechatronic and robotic systems

An analysis of the programs of disciplines studied by masters also shows that almost all disciplines currently have a component associated with the use of modern information technologies.

In this regard, ensuring the continuity of training within the framework of a single concept for the use of software comes to the fore.

\section{Strengthening interdepartmental relations in the framework of the use of computer technology}

An important task in the training of engineers is the formation of communicative competencies of a special type that ensure mutual understanding of specialists from different industries in the framework of creating a single complex system. 


\subsection{The first step is a single training in the field of application of basic software}

In Fig. 3 the structure of the most used software is shown (the results of the analysis of the programs of disciplines of BMSTU related to computer modeling).

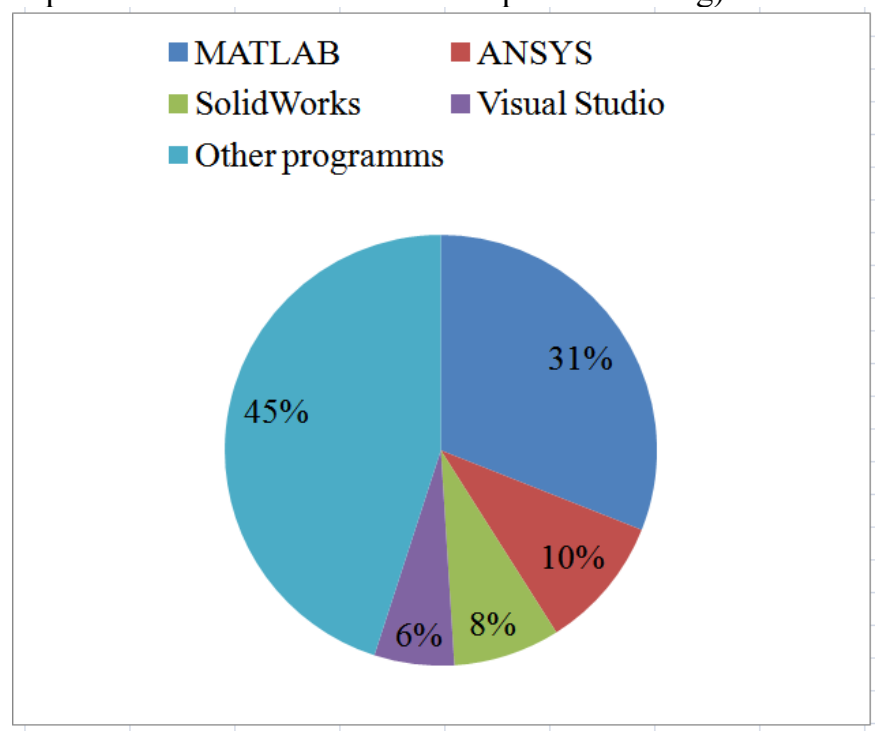

Fig. 3. Software packages.

\subsection{Deeper inter-department training}

It can be achieved through the mutual reading of disciplines that form the appearance of an engineer with wide profiles in an enlarged direction, for example, in the field of special engineering. There is such experience, but one can go for even deeper integration through the creation of a common integrated program. Such a unifying program can serve, for example, the theme "Software and hardware systems for simulation and training for facility management".

Training technologies today are complex systems, modeling and simulation systems, computer programs and physical models, special techniques created in order to prepare a person for making high-quality and quick decisions. Obviously, in such programs, computer modeling can play a decisive role not only as a means of solving practical problems, but also as a means of interdepartmental integration. Simulators today are characterized by the use of machine learning principles along with traditional approaches, when the simulator is able to develop along with the trainee. The main parts of the simulator, such as a modeling computer, operator interface, instructor station, simulation models used in a simulation computer, realistically reflect the interaction of components and systems of the simulated process.

The following is a list of inter-department disciplines based on the use of integrating computer technologies:

- information systems and technologies in mechatronics and robotics;

- algorithms and software for robotic and mechatronic systems;

- microprocessor devices of control systems;

- fundamentals of scientific research and testing of wheeled and tracked vehicles;

- computer-aided design; 
- mathematical modeling of work processes of ground transportation and technological complexes

- orientation and navigation systems;

- motion control of aircraft.

\section{The main trends and requirements for the use of computer modeling}

\subsection{Fundamental trends}

At the present stage, the following fundamental trends can be identified:

- Implementation of a systematic approach to modeling;

- Support for semi-natural modeling by connecting an increasing number of devices from different manufacturers;

- Organization of interaction between different software products;

- Expansion of application areas;

- Interaction and mutual enrichment of various disciplines;

- Continuity in the use of the modeling method in accordance with the curriculum;

- Formation of an electronic educational environment.

\subsection{Systems approach}

Computer programs and systems aimed at software support for modeling should meet the mandatory requirement of a systematic approach, i.e. Support the following model requirements:

- integrity;

- the presence of the objective function;

- hierarchical structure;

- the presence of a large number of elements;

- elements interact over time;

- Elements are combined into subsystems;

- subsystems have a sufficient number of direct and feedbacks between each other (each subsystem has a local objective function).

\subsection{Application of the principles of the engineering school of MSTU. N.E. Bauman in approaches to computer modelling}

In Fig. 4 a diagram showing the features of an engineering school is shown and the duality of the requirements for the implementation of computer modeling is noted. 
Traditions of the engineering school of BMSTU

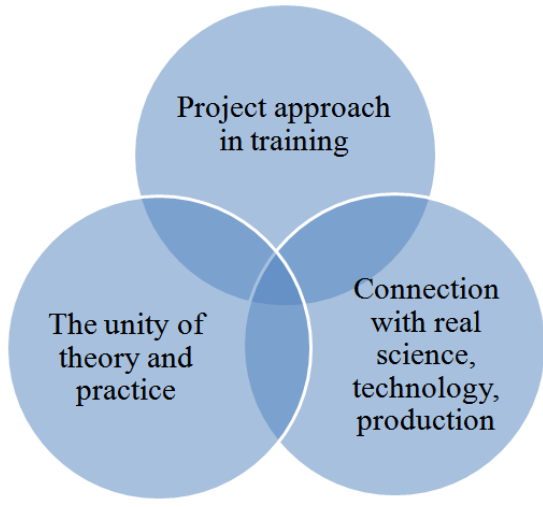

Modeling in BMSTU

Fig. 4. Engineering school and modeling in BMSTU.

\subsection{Analysis and synthesis are two sides of the process of effective computer modelling}

The most important methodological aspect of the application of modeling is its bidirectionality: analysis and synthesis.

In Fig. 5 an example of the application of computer modeling technologies as part of the development of DAC-ADC (digital-to-analog and analog-to-digital converters) is shown. The task is of great practical importance in at least two aspects:

- direct use in control systems having a digital and analog part;

- use in semi-natural modeling and computer design, when the individual elements of the system have a different nature.

\section{TASKS OF DAC-ADC MODELING}

PIDENTIFICATION OF TASKS

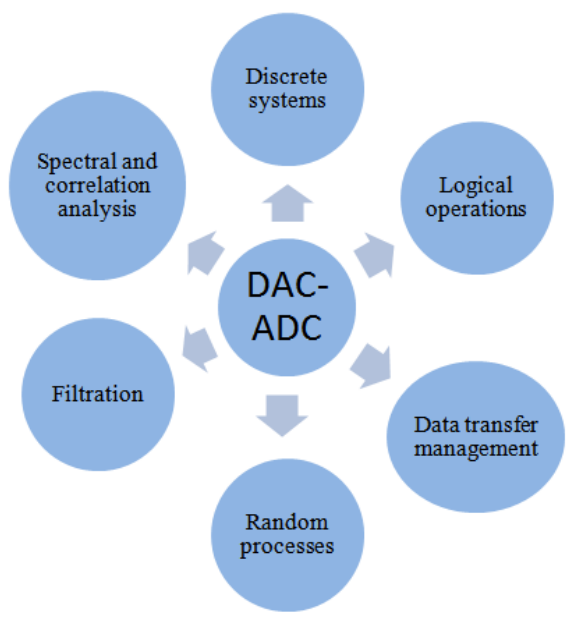

KNOWLEDGE INTEGRATION

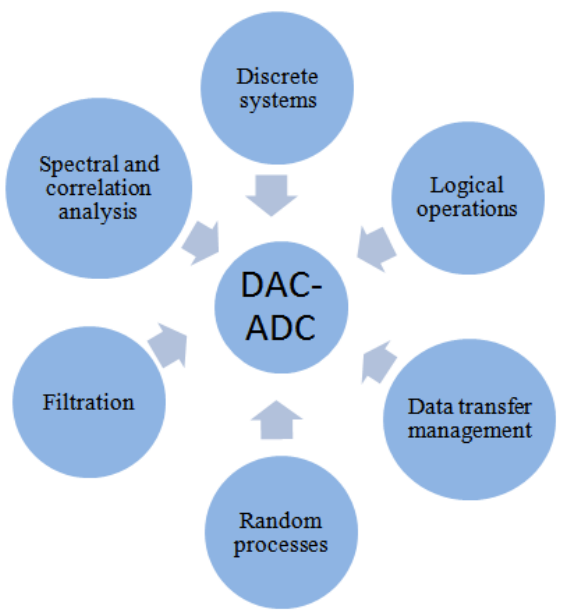

Fig. 5. Application of computer modeling technologies as part of the development of DAC-ADC. 
Modern computer technology in engineering training offers great modeling opportunities. For example, technologies of parallel computing are actively used. However, with the growth of technical and software capabilities, the volume of computations also grows. Therefore, it is necessary to form competencies for the efficient use of computing resources [1].

\subsection{Using integrated software products}

Currently, there is a clear tendency to use integrated software products. An example of a structure for integration is MATLAB.

For example, to develop control systems, the following related products are used:

- Calculation - Toolbox ${ }^{\text {TM }}$ Management System, Toolbox TM Optimization

- Visualization [2] - Virtual Worlds, Simulink® 3D Animation TM;

- Implementation - microcontrollers; (dspMicrochip example); FPGA programmable logic integrated circuits (e.g. Altera TM products); PLC programmable logic controllers (Fastwel TM example).

In Fig. 6 showing examples of integrated products with MATLAB.
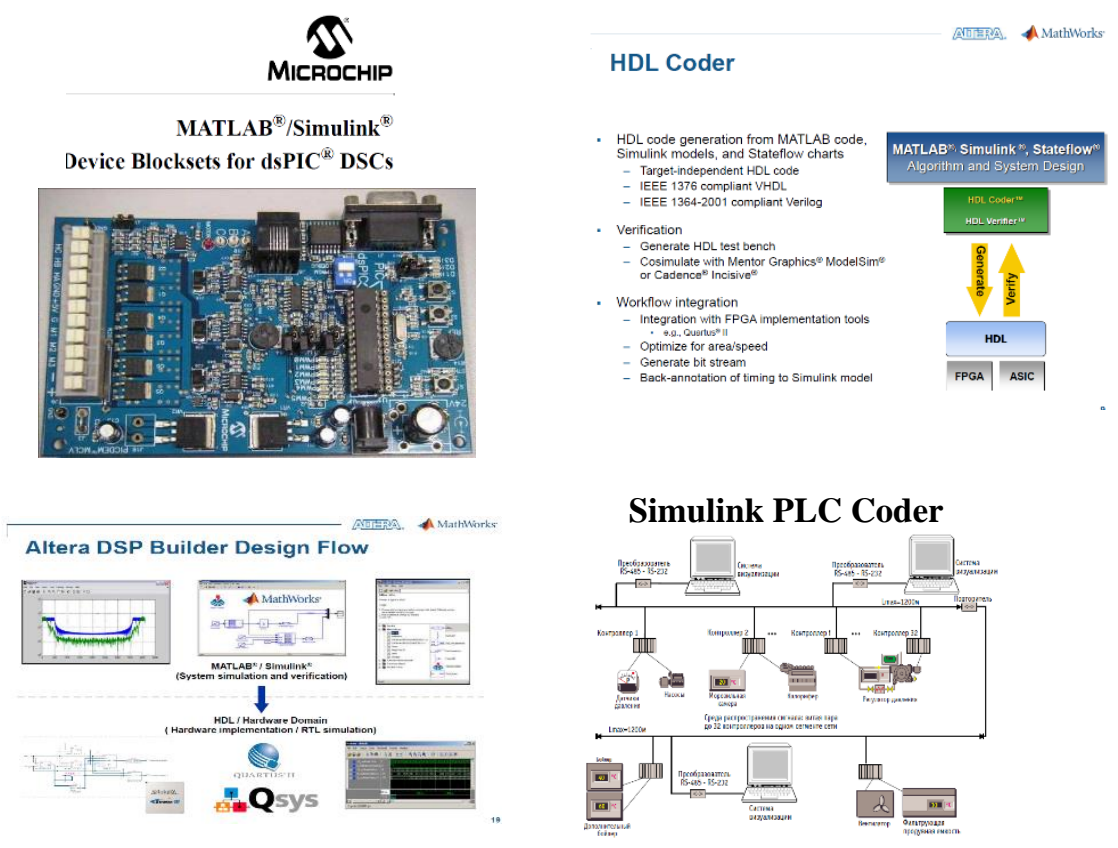

Fig. 6. Examples of integrated products with MATLAB.

An important advantage of such products is the possibility of dual use (Fig. 7):

- three practical tasks of automated research and design

- tasks of forming competencies in the field of scientific and design activities. 


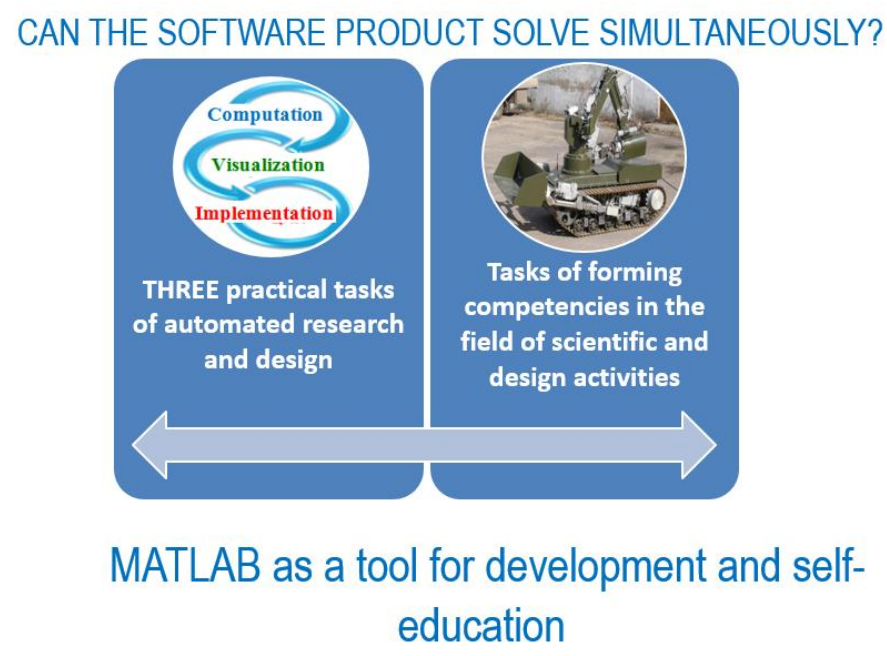

Fig. 7. MATLAB development and self-development tool.

\section{Conclusions}

At this stage, the digitalization of education opens up wide opportunities for improv-ing the training of future engineers and it is important to fully ensure the methodolog-ical component of their application in the trinity: student - teacher - employer. The active use of integrated software products allows you to build practical skills for a comprehensive solution to an engineering problem. A digital educational environment is actively used, in particular, it is preferable to conduct monitoring of training in the same software products on which students are trained. The main modern trends are active training and teamwork, group training. These computer technologies have taken the project approach to learning to a new stage. New software products allow not only the formation of special competencies, but also provide the opportunity to acquire important communication skills. New opportunities for student motivation are opening up.

Open training, access to open source software in engineering and other fields made it possible to take students to a new level of self-education, without which the work of an engineer is impossible in rapidly changing conditions, and which, undoubtedly, requires an attentive look and control of teachers.

\section{References}

1. I.K. Romanova, Povysheniye effektivnosti vychislitel'nykh eksperimentov pri modelirovanii dvizheniya letatel'nykh apparatov, Mashinostroyeniye i komp'yuternyye tekhnologii, № 7, pp. 158-188 (2017). DOI: http://dx.doi.org/10.7463/0717.0001269

2. I.K. Romanova, Sovremennyye metody vizualizatsii mnogomernykh dannykh: analiz, klassifikatsiya, realizatsiya, prilozheniya $v$ tekhnicheskikh sistemakh, Nauka i obrazovaniye, № 3, pp. 133- 167 (2016). DOI: 10.7463/0316.0834876.

3. M.A.C. Pereira, M.A.M. Barreto \& M. Pazeti, Application of Project-Based Learning in the first year of an Industrial Engineering Program: lessons learned and challenges, Production, 27(spe), e20162238 (2017). DOI http://dx.doi.org/10.1590/01036513.223816 
4. M.L. Calderon, Application of reverse engineering activities in the teaching of engineering design, INTERNATIONAL DESIGN CONFERENCE - DESIGN 2010, Dubrovnik - Croatia, May 17 - 20, pp. 1249-1258 (2010)

5. D. Moud, S. Bijawat, S. Tuli, B. Bhardwaj, An analysis to find effective teaching methodology in engineering education, IEEE International Conference in MOOC, Innovation and Technology in Education (MITE) 978-1-4799-1626-9/13/ 2013, pp. 185-189 (2013)

6. M. C. Rodriguez-Sanchez, A. Torrado-Carvajal, J. Vaquero, S. Borromeo and J. A. Hernandez-Tamames, An Embedded Systems Course for Engineering Students Using Open-Source Platforms in Wireless Scenarios, IEEE TRANSACTIONS ON EDUCATION, January 18, 2016., 0018-9359 (C) 2016 IEEE (0216). DOI 10.1109/TE.2016.2526676

7. A. Martins, E. Pinto, Eduscrum - the empowerment of students in engineering education?, Proceedings of the 12th International CDIO Conference, Turku University of Applied Sciences, Turku, Finland, June 12-16 (2016)

8. A. García-Holgado, F. J. García-Peñalvo \& M. J. Rodríguez-Conde, Pilot experience applying an active learning methodology in a Software, Engineering classroom 2018 IEEE Global Engineering Education Conference (EDUCON), 17-20 April 2018, Santa Cruz de Tenerife, Canary Islands, Spain, pp. 946-953 (2018). USA: IEEE.

9. C.S. Ramos, R.A.D. Kosloski, E. Venson, R.M. da C. Figueiredo, TBL as an active learning-teaching methodology for software engineering courses, Conference: the XXXII Brazilian Symposium· September 2018 (2018)DOI: 10.1145/3266237.3266253

10. C. Rosicka, From concept to classroom. Translating STEM education research into practice, Australian Council for Educational, June 2016, p. 16 (2016). www.acer.edu.au/epp/translational-research

11. J. Capacho, Dr. Teaching And Learning Methodologies Supported By Ict Applied In Computer Science, Turkish Online Journal Of Distance Education-Tojde April 2016, Issn 1302-6488, Vol. 17, No. 2, Article 5, pp. 59-73 (2016)

12. M. Dalal, Impact of Multi-media Tutorials in a Computer Science Laboratory CourseAn Empirical Study, The Electronic Journal of e-Learning, Vol. 12, I. 4, pp. 366-374 (2014). available online at www.ejel.org

13. V. Meana, A. Bello, R. García, Analysis of the implementation of the BIM methodology in the spanish industrial engineering degrees under the competential perspective, Revista Ingeniería de Construcción RIC, Vol. 34, No. 2, pp. 169-180 (2019). www.ricuc.cl

14. S. Moazeni, Effective Strategies to Teach Operations Research to Non-Mathematics Majors, University of Waterloo, 200 University Avenue West, Waterloo, Ontario, Canada N2L 3G1. (This research project is intended toward Certi_cate in University Teaching Program (GS 902)), p. 24

15. P. Häfner, V. Häfner, J. Ovtcharova, Teaching Methodology for Virtual Reality Practical Course in Engineering Education, 2013 International Conference on Virtual and Augmented Reality in Education, Procedia Computer Science 25, pp. $251-260$ (2013)

16. D. Mohovic, R. Mohovic and M. Baric, Deficiencies in Learning COLREGs and New Teaching Methodology for Nautical Engineering Students and Seafarers in Lifelong Learning Programs, THE JOURNAL OF NAVIGATION, No. 69, pp. 765-776 (2016). (C) The Royal Institute of Navigation 2016. doi:10.1017/S037346331500096X 
17. M. Alkhattabi, Augmented Reality as E-learning Tool in Primary Schools' Education: Barriers to Teachers' Adoption, iJET, Vol. 12, No. 2, pp. 91-100 (2017). https://doi.org/10.3991/ijet.v12i02.6158

18. T. Rizov, E. Rizova, Augmented reality as a teaching tool in higher education, (IJCRSEE) International Journal of Cognitive Research in Science, Engineering and Education, Vol. 3, No.1, pp. 7- 16 (2015). www.ijcrsee.com.

19. M. Berenguel, F. Rodriguez, J-E. C. Moreno, J. E. L. Guzman, R. Gonzalez, Tools and Methodologies for Teaching Robotics in Computer Science \&Engineering Studies, 2015Wiley Periodicals, Inc. Comput Appl Eng Educ, No. 24, pp. 202-214, (2016).View this article online at wileyonlinelibrary.com/journal/cae; DOI $10.1002 /$ cae. 21698

20. F.M-L. Rivera, J.C. Vielma, R.H. Herrera, Methodology for Building Information Modeling (BIM) Implementation in Structural Engineering Companies (SECs), Hindawi Advances in Civil Engineering, Article ID 8452461, p. 16 (2019). https://doi.org/10.1155/2019/8452461

21. C. Fulton, Innovating with Digital Badges in Assessment: A Case Study Using Digital Badges in an Undergraduate University Module, AISHE-J, Vol. 11, No. 3, Autumn 2019, pp. 1-13 (2019)

22. R.M. Felder, R. Brent, M.J. Prince, Engineering instructional development: programs, best practices, and recommendations, Journal of Engineering Education, 100(1), pp. 89 $-122(2011)$

23. M. Jennifer, J.M. Case, G. Light, Emerging Methodologies in Engineering Education Research, Journal of Engineering Education January 2011, Vol. 100, No. 1, pp. 186210 (2011). (C) 2011 ASEE. http://www.jee.org

24. K. Kobata, H. Adachi, M. Aoyama, Curriculum development professional software engineers and its evaluation, 2014 International Conference of Teaching, Assessment and Learning (TALE), 08-10 December 2014, Wellington, New Zealand. pp. 480-487 (2014). 978-1-4799-7672-0/14/\$31.00 (C2014 IEEE

25. R.T. Mason, W. Masters, A. Stark, Teaching Agile Development with DevOps in a Software Engineering and Database Technologies Practicum, 3rd International Conference on Higher Education Advances, HEAd'17Universitat Polit'ecnica de Val'encia, Val'encia, pp. 1353- 1362 (2017). DOI: http://dx.doi.org/10.4995/HEAd17.2017.5607

26. S. Teel, D. Schweitzer and S. Fulton, Teaching Undergraduate Software Engineering Using Open Source Development Tools, Informing Science and Information Technology, Vol. 9, p. 11 (2012)

27. S. W. Lee and D. Rine, Case Study Methodology Designed Research in Software Engineering Methodology Validation, Proceedings of the Sixteenth International Conference on Software Engineering and Knowledge Engineering (SEKE'04), pp. 117122, Banff Centre, Banff, Alberta, Canada, June 20 to June 24 (2004)

28. V. Subbian, C.C. Purdy, A Hybrid Design Methodology for an Introductory Software Engineering Course with Integrated Mobile Application Developmen, 121 st ASEE Annual Conferecne \& Exploration/ Indianapolis, IN June 15-18 (2014)

29. N. Tillmann, J. Halleux, T. Xie, S. Gulwani, J. Bishop, Teaching and Learning Programming and Software Engineering via Interactive Gaming, Computer Science. Published in 35th International Conference 2013 (2013). DOI:10.1109/ICSE.2013.6606662 
30. H. Acar, Software development methodology in a Green IT Environment, HAL Id: tel01724069, p. 121 (2018). https://tel.archives-ouvertes.fr

31. A. Santos, A. Sales, P. Fernandes and M. Nichols, Combining Challenge-Based Learning and Scrum Framework for Mobile Application Development, Association for Computing Machinery (ACM) in Proceedings of the 2015 ACM Conference on Internet Measurement Conference - IMC '15, 1 January 2015, pp. 189-194 (2015). DOI:10.1145/2729094.2742602 . 